\title{
Cellular inactivation of nitric oxide induces p53-dependent apoptosis in human melanoma cells
}

\author{
Seo Hyun Moon ${ }^{1,2}$, Myung Haing $\mathrm{Cho}^{2-6}$ and Min Young $\mathrm{Kim}^{7,8 *}$ \\ ${ }^{1}$ Department of Forensic DNA, National Forensic Service, Wonju, Gangwon-do 220-170, ${ }^{2}$ Laboratory of Toxicology, College of \\ Veterinary Medicine, 151-742, ${ }^{3}$ Graduate Group of Tumor Biology, Seoul 110-799, ${ }^{4}$ Graduate School of Convergence Science \\ and Technology, ${ }^{5}$ Advanced Institutes of Convergence Technology, Seoul National University, Suwon 443-270, ${ }^{6}$ Institute of \\ GreenBio Science Technology, Seoul National University, Pyeongchang-gun, Gangwon-do 232-916, 'Toxicology Laboratory, \\ Major in Biomaterials, College of Applied Science, SARI, ${ }^{8}$ Research Institute for Subtropical Agriculture and Biotechnology, Jeju \\ National University, Jeju 690-756, Republic of Korea
}

*For correspondence: Email: jeffmkim@jejunu.ac.kr; Tel: +82-64-754-3349; Fax: +82-64-756-3351

Received: 6 May 2016

Revised accepted: 22 July 2016

\begin{abstract}
Purpose: To examine the role of endogenous nitric oxide (NO) and influence of p53 status during apoptosis induced by a selective iNOS inhibitor, N-[(3-aminomethyl) benzyl] acetamidine (1400W), and/or an NO' scavenger carboxy-PTIO (c-PTIO) in two isogenic human melanoma cell lines, wild-type p53 (A375) and p53 mutant (SK mel-28) cells.

Methods: 3-(4,5-Dimethylthiazol-2-yl)-2,5-Diphenyltetrazolium Bromide (MTT) and Annexin V/propidium iodide assay were used to test for antiproliferation and apoptosis, respectively. Griess and reverse transcription-polymerase chain reaction (RT-PCR) reactions were carried out to assay NO production and the $m R N A$ levels of inhibitors of apoptosis (IAP).

Results: c-PTIO and 1400W, alone or in combination, inhibited cell growth and promoted apoptosis via sub-G1 cell cycle arrest mediated by decrease in NO. Apoptosis was delayed and greatly reduced in magnitude in SK mel-28 cells, underscoring the importance of p53 modulation of the response. In both cell types, apoptosis induced by iNOS inhibition and/or NO' depletion was blocked by an exogenous $N^{\circ}$ donor, sodium nitroprusside. It was also found that inhibitors of apoptosis family (survivin, XIAP and cIAP1) were significantly depressed, which appear to play an important role in the regulation of p53mediated apoptotic response under these conditions.

Conclusion: The data obtained provide insight into the mechanism of cell proliferation action of endogenous NO', based on p53 status, and indicate manipulation of iNOS may offer exciting opportunities to improve the effectiveness of melanoma treatment.
\end{abstract}

Keywords: Apoptosis, Human melanoma cells, Inducible nitric oxide synthase, p53

Tropical Journal of Pharmaceutical Research is indexed by Science Citation Index (SciSearch), Scopus, International Pharmaceutical Abstract, Chemical Abstracts, Embase, Index Copernicus, EBSCO, African Index Medicus, JournalSeek, Journal Citation Reports/Science Edition, Directory of Open Access Journals (DOAJ), African Journal Online, Bioline International, Open-J-Gate and Pharmacy Abstracts

\section{INTRODUCTION}

Melanoma is the most devastating skin cancer with the highest increase in incidence in recent years [1]. Melanoma originates from a malignant degenerated melanocyte, which is a highly aggressive tumor cell with poor rates of survival once it has metastasized. Melanoma is intrinsically resistant to treatments such as radiation and conventional chemotherapy, for possible reasons that involve drug-detoxifying properties of melanosomes [2], energy dependent drug efflux pumps [3], overexpression of inhibitors of apoptosis [4], altered expression of oncogenes or tumor suppressors [4] and endogenous nitric oxide (NO*) [5]. Evidently, 
investigating the leading drug resistant mechanisms and how to reverse or circumvent them would be critical steps in developing effective new therapies for melanoma patients.

$\mathrm{NO}^{\circ}$ produced naturally by $\mathrm{NO}^{\circ}$ synthase (NOS) enzymes plays a role in many different physiological processes, including vasodilation, neurotransmission, antimicrobial action, inflammation and cancer [6]. The NO released by the constitutive enzymes neuronal NOS (nNOS) and endothelial NOS (eNOS) acts as an important signaling molecule in the cardiovascular and nervous systems [6] and $\mathrm{NO}^{\circ}$ released by the inducible NOS (iNOS) is generated for long periods, by cells of the immune system among others, and has been shown to be principally involved in inflammatory processes and cancer formation [6].

The role for $\mathrm{NO}^{\circ}$ in tumor biology is multidimensional. High level of $\mathrm{NO}^{\circ}$ has been proposed to be cytotoxic for cancer cells. By contrast, at low level, constitutive production of endogenous $\mathrm{NO}^{\circ}$ can promote tumor growth by inducing anti-apoptotic effects in many tumor types including melanoma [7]. Whether iNOSderived $\mathrm{NO}^{\circ}$ has any positive or negative effect on tumor progression, however, is still poorly understood. Numerous reports have suggested that growth and metastasis of solid tumors such as oral squamous cell carcinoma [8], breast cancer [9], melanoma [10], colon cancer [11] and gynecological malignancies [12] is correlated with an enhanced expression of iNOS. On the other hand, it has been reported that overexpression of iNOS gene can suppress tumor survival and metastasis of melanoma [13] and renal carcinoma cells [14]. From these paradoxical reports, iNOS seems to be related to anticancer as well as carcinogenesis.

The aim of the present study was to assess the inhibitory effects of endogenous $\mathrm{NO}^{\circ}$ on the proliferation of human melanoma cells by employing a selective iNOS inhibitor $1400 \mathrm{~W}$, an $\mathrm{NO}^{\circ}$ scavenger carboxy-PTIO (c-PTIO) and an $\mathrm{NO}^{\circ}$ donor sodium nitroprusside (SNP) for modulating $\mathrm{NO}^{\circ}$ consumption. The mechanisms of apoptotic cell death and the role of IAP family in the process were also investigated.

\section{EXPERIMENTAL}

\section{Cell cultures and chemicals}

The choice of human tumor cells was based on p53 status. The cell line (both were a gift from Dr.
G. N. Wogan, Massachusetts Institute of Technology) used were human melanoma A375 (p53 wild-type) and SK mel-28 (p53 mutant, point mutation in codon 145 of p53) cells. The cells were grown in high glucose Dulbecco's modified Eagle's medium (DMEM) supplemented with 10 $\%$ heat-inactivated fetal bovine serum (FBS), 100 units $/ \mathrm{ml}$ penicillin, $100 \mu \mathrm{g} / \mathrm{ml}$ streptomycin and 2 $\mathrm{mM}$ L-glutamine at $37^{\circ} \mathrm{C}$ in $5 \% \mathrm{CO}_{2}$ and cultured every few days to maintain exponential growth. Reagents and cell culture materials were purchased from the following sources: cell culture materials, Lonza (Walkersville, MD, US); Fetal Bovine Serum (FBS), PAA Laboratories (Coelbe, Germany); 1400W dihydrochloride, 2(4-Carboxyphenyl)-4,4,5,5-

tetramethylimidazoline-1-oxyl-3-oxide (c-PTIO) and sodium nitroprusside (SNP), Sigma Chemical (St. Louis, MO, USA); N-methyl-Larginine monoacetate (NMA) and cisplatin, CalBiochem (Salt Lake City, UT, USA).

\section{Cell viability assay}

The number of viable cells was estimated by measurement of the rate of mitochondrial metabolism of 3-(4,5-dimethylthiazol-2-yl)-2,5diphenyltetrazolium bromide (MTT) using a cell proliferation kit I (Roche, Indianapolis, IN, USA) according to the manufacturer's instructions. Briefly, cells were plated at $5 \times 10^{4}$ cells/well in $100 \mu \mathrm{L}$ volume in 96-well plates and were then grown for $24 \mathrm{~h}$ in DMEM supplemented with 10 $\%$ FBS. Different concentrations of test drugs or DMSO $0.1 \%$ were added to the wells for the designated time points.

Cells were then incubated with $10 \mu \mathrm{L}$ of MTT (5 $\mathrm{mg} / \mathrm{ml}$ ) at $37{ }^{\circ} \mathrm{C}$ in the dark for $4 \mathrm{~h}$. The tetrazolium crystals were solubilized by the addition of $100 \mu \mathrm{L}$ of $10 \%$ SDS in $0.01 \mathrm{~N} \mathrm{HCl}$. After overnight incubation at $37{ }^{\circ} \mathrm{C}$, the absorbance was measured at $550 \mathrm{~nm}$ using a Packard EL340 microplate reader (Bio-Tek Instruments, Winooski, VT, US). The relative percentage of cell survival was calculated by dividing the absorbance of treated cells by that of the control in each experiment. Results from the MTT assay have been used to derive the $50 \%$ effective concentrations $\left(E_{50}\right)$ of each drug to induce growth inhibition.

\section{Apoptosis analysis}

Apoptosis after treatment was quantitatively evaluated with a Becton Dickinson FACScan equipped with CellQuest software following annexin V-FITC and propidium iodide staining (Clontech Laboratories, Palo Alto, CA) following procedures reported previously [11]. 


\section{Cell cycle analysis}

Cells were seeded in 100-mm tissue culture dishes at a density of $2 \times 10^{6} \mathrm{cells} / \mathrm{ml}$ and were treated with $1400 \mathrm{~W}$ and/or c-PTIO in the presence or absence of SNP for $72 \mathrm{~h}$. The cells were harvested, washed twice in PBS and fixed in $70 \%$ cold ethanol overnight. They were then suspended in $1 \%$ BSA (bovine serum albumin)PBS solution containing $500 \mu \mathrm{g} / \mathrm{ml}$ propidium iodide and $10 \mu \mathrm{g} / \mathrm{ml} \mathrm{RNase,} \mathrm{incubated} \mathrm{at} 37^{\circ} \mathrm{C}$ for $30 \mathrm{~min}$ and analyzed with a Becton Dickinson FACScan (BD Bioscience, San Jose, CA, USA). Cell fit analysis determined the percentage of cells in a specific stage of the cell cycle using CellQuest software, and expressed as a percentage of cells in the respective phases.

\section{DNA fragmentation analysis}

Isolation of DNA and analysis by agarose gel electrophoresis were done using a GenEluteTM mammalian genomic DNA miniprep kit (Sigma) as described [11]. Isolated DNA was suspended in TE buffer $(10 \mathrm{mM}$ Tris- $\mathrm{HCl}, 1 \mathrm{mM}$ EDTA, $\mathrm{pH}$ 9.0 ) and quantified by absorbance at $260 \mathrm{~nm}$. Fragmented DNA was loaded onto $1.8 \%$ agarose gel containing $1 \times$ TBE buffer and separated by electrophoresis for $2 \mathrm{~h}$ at $50 \mathrm{~V}$, then photographed after staining with $0.5 \mathrm{ng} / \mathrm{ml}$ ethidium bromide.

\section{Measurement of nitrite production}

$\mathrm{NO}^{\circ}$, resulting from NOS, reacts rapidly with $\mathrm{O}_{2}$ and accumulates in the culture medium as nitrite and nitrate. NO production was assessed by measuring nitrite in media fractions by the Griess reaction as previously described [15]. Optical density was measured using a microplate reader at $540 \mathrm{~nm}$, with fresh culture media serving as the blank. Determinations were performed in triplicate. The values were obtained by comparison with standard concentrations of sodium nitrite and expressed as pmoles per $10^{6}$ viable (trypan blue-excluding) cells.

\section{Semiquantitative RT-PCR analysis}

Total RNA was extracted using the Tri Reagent kit from Sigma and semiquantitative RT-PCR analysis was performed using the TOP script ${ }^{\mathrm{TM}}$ one-step RT PCR kit (Enzynomics, Daejeon, Korea) following the manufacturer's recommended protocol. Two $\mu \mathrm{g}$ total RNA were used in each reaction. Primer sequences were as follows : for nNOS, sense 5'TTGGGGGCCTGGGATTTCTGG-3', antisense, 5'-GTTGGCATGGGGGAGTGAGC-3'; for iNOS, sense 5'-CCAGTGACACAGGATGACCTTCAG-
3', antisense 5'-TGCCATTGTTGGTGGAGTAAC G-3ᄀ'; for eNOS, sense 5'-CCAGCTAGCCAA AGTCACCAT-3 $\neg$ ', antisense 5'-GTCTCGGAGC CATACAGGATT-3ᄀ'; for survivin, sense 5'GCATGGGTGCCCCGACGTTG-3 $\neg$ ', antisense 5'-GCTCCGGCCAGAGGCCTCAA-3'; for XIAP, sense 5'-ACACCATATACCCGAGGAAC-3ᄀ', antisense 5'-CTTGCATACTGTCTTTCTGA GC3ᄀ'; for ClAP-1, sense 5'-AAGTTCCTAC CCCTGTCCAATG-3 $\neg$ ', antisense 5'-CAAGTAGA TGAGGGTAACTGGC-3'?'; for clAP-2, sense 5'CCTGTGGTTAAATCTGCCTTG-3 $\neg$ ', antisense 5'-CAATTCGGCACCATAACTCTG-3ح'; for $\beta$ actin, sense 5'-GGTCATCTTCTCGCGGTTGG CCTTGGGGT-3', antisense 5'-CCCCAGGC ACCAGGGCGTGAT-3'. Amplified DNA was electrophoresed on $1.5 \%$ agarose gels and visualized by ethidium bromide staining.

\section{Statistical analysis}

Where necessary, statistical analysis was done by two-tailed Student's t-test or one-way analysis of variance (ANOVA). Values of $p<0.05$ were considered statistically significant.

\section{RESULTS}

\section{Effect of $\mathrm{NO}^{\circ}$ on melanoma proliferation}

A375 cells treated with an $\mathrm{NO}^{\circ}$ scavenger c-PTIO $(0.1,0.2$ and $0.4 \mathrm{mM})$, a specific iNOS inhibitor 1400W (1, 2 and $4 \mathrm{mM}$ ) and the nonspecific inhibitor of NOS NMA (1,2 and $4 \mathrm{mM})$ for $48 \mathrm{~h}$ responded with respect to viability, in that all treatments decreased the percentage of viable cells dose-dependently (Figure 1A). The median effective concentration $\left(E_{50}\right)$ with c-PTIO, 1400W and NMA to cause cell growth inhibition was found to be $0.12,2.04$ and $4.05 \mathrm{mM}$, respectively (Figure $1 \mathrm{~A}$ ). We subsequently investigated the time-course of responses to 0.4 $\mathrm{mM}$ c-PTIO, $4 \mathrm{mM}$ 1400W and $4 \mathrm{mM} \mathrm{NMA}$, in A375 and SK mel-28 cells treated for 24, 48 and $72 \mathrm{~h}$. Treatment of both cells with NOS inhibitors and NO' scavenger caused a time-dependent decrease in cell proliferation (Figures $1 \mathrm{~B}$ and $\mathrm{C}$ ). In comparison to A375 (p53 wild-type) cells, SK mel-28 (p53 mutant) cells were resistant to $\mathrm{NO}^{\circ}$ modulators-induced cell death (Figures $1 \mathrm{~B}$ and C).

Nitrite production was measured in culture media following treatment for $72 \mathrm{~h}$. Significant levels of nitrite were detected in the culture medium of A375 and SK mel-28 cells (Figure 1D). Cells treated with $4 \mathrm{mM} 1400 \mathrm{~W}$ and/or $400 \mu \mathrm{M}$ c-PTIO for $72 \mathrm{~h}$ showed 1.3- to 2.8-fold decreases in nitrite level, as compared with untreated controls. 
p53 wild-type $\mathrm{A} 375$ cells produced $\mathrm{NO}^{\circ}$ at higher concentrations than p53 mutant SK mel-28 cells (Figure 1D); for example, the nitrite level in p53WT cells (1.7 pmoles $/ 10^{6}$ cells) was thrice that of p53-null cells ( 5 pmoles $/ 10^{6}$ cells) after $72 \mathrm{~h}$ of $400 \mu \mathrm{M}$ c-PTIO treatment.

\section{NO reduces loss of viability induced by cisplatin}

To evaluate the role of endogenous $\mathrm{NO}^{\circ}$ in melanoma cell survival, we determined the proliferation of $A 375$ cells at $48 \mathrm{~h}$ by the addition of various concentration of the NO donor SNP. As shown in Figure 2A, A375 cell proliferation was slightly increased by SNP at concentrations of $0.1-100 \mu \mathrm{M}$. Treatment of cells with more than $100 \mu \mathrm{M}$ SNP caused a dose-dependent decrease in cell viability $(p<0.05)$.

Next, to verify whether endogenous $\mathrm{NO}^{\circ}$ modulation regulates growth inhibition after cisplatin treatment; we incubated cells with cisplatin alone or in combination with $1400 \mathrm{~W}$ and C-PTIO (Figure 2B). Cisplatin (cisdiamminedichloroplatinum(II)), the drug of choice for the treatment of tumors, selectively and persistently inhibits the synthesis of DNA and RNA [16].

A

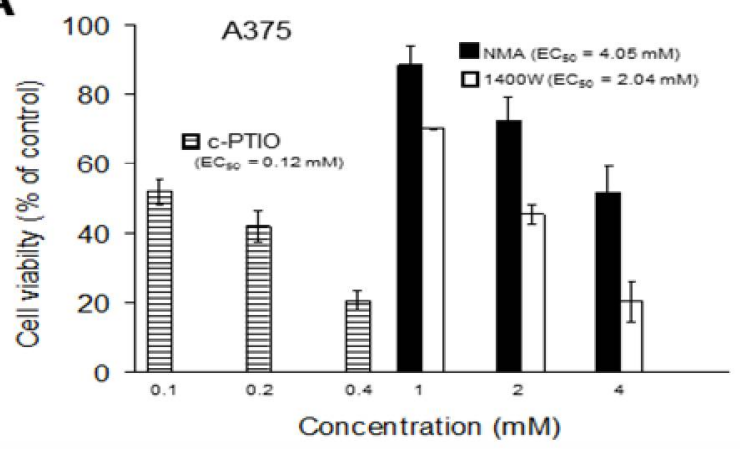

B

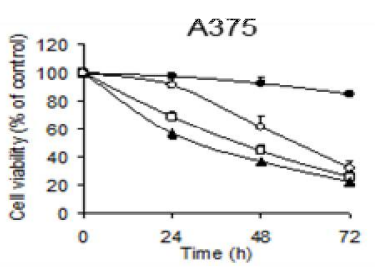

$4 \mathrm{mM}$ NMA $\square 4 \mathrm{mM} 1400 \mathrm{~W}$ A00 $\mathrm{M} \mathrm{CPTO}$ O 4 mM NMA pretreated with 200 uM c. PTO for in

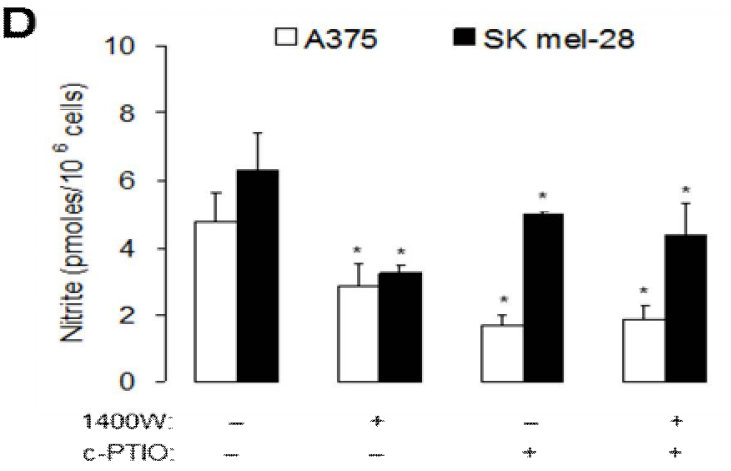

Figure 1: Cell viability and intracellular nitrite level of A375 and SK mel-28 cells after NOS inhibition by NMA and $1400 \mathrm{~W}$, or $\mathrm{NO}^{\circ}$ scavenging by c-PTIO. A375 cells were treated with the various concentrations of $\mathrm{NO}^{\circ}$ modulators for $48 \mathrm{~h}(\mathrm{~A})$. A375 (B) and SK mel-28 (C) cells were incubated at indicated concentrations of NO modulators (box) for 24, 48 and $72 \mathrm{~h}$. The $\mathrm{EC}_{50}$ values (the effective concentration of the $\mathrm{NO}$ modulators that reduced cell survival by $50 \%$ ) were determined by the MTT assay. A375 and SK mel-28 cells were treated with $1400 \mathrm{~W}$ (4 mM) or c-PTIO $(400 \mu \mathrm{M})$ alone, or combination (4 mM of $1400 \mathrm{~W}$ pre-incubated with $200 \mu \mathrm{M}$ of c-PTIO for $24 \mathrm{~h}$ ) (D). Results are presented as a percentage of control cells (mean $\pm \mathrm{SD}, \mathrm{n}=3$ ). ${ }^{*} p<0.05$ versus control 
In this study, cell viability significantly decreased by 78 and $93 \%$ after cisplatin treatment in A375 and SK mel-28 cells, respectively $(p<0.05)$. When cells were co-incubated with both cisplatin and $\mathrm{NO}^{\circ}$ modulators, viability significantly decreased by 3-folds over that which was induced by cisplatin alone in both cells $(p<$ 0.05). Moreover, the concomitant addition of $\mathrm{SNP}$, a $\mathrm{NO}^{\circ}$ donor, with $\mathrm{NO}^{\circ}$ modulators caused cell re-growth, which indicates that the antiproliferative effect was specific to endogenous $\mathrm{NO}^{\circ}$ depletion $(p<0.05)$ (Figure 2B).

\section{Apoptosis identified by flow cytometric analysis}

To investigate the potential role of $\mathrm{NO}^{\circ}$ in apoptosis regulation, A375 and SK mel-28 cells were treated with $\mathrm{NO}^{\circ}$ modulators and donors SNP. Figure 3 shows that the iNOS inhibitor $1400 \mathrm{~W}$ and/or the $\mathrm{NO}^{\circ}$ scavenger c-PTIO effectively increased the cellular response to cell death, whereas those co-treated with the $\mathrm{NO}^{\circ}$ donor SNP had an opposite effect. A stronger apoptotic response was induced in A375 (p53 wild-type) cells than in SK mel-28 (p53 mutant) cells (Figure 3 ). Approximately 71-74 and 40-70 $\%$ of A375 and SK mel-28 cells (19- and 8-fold over control level), respectively, were apoptotic after treatment with 1400W and/or c-PTIO (Figure 3).

\section{Cell cycle distribution}

By FACS analysis of cell DNA content, there was a remarkable accumulation of subploid cells, sub-G1 peak, in A375 and SK mel-28 cells after treatment with $\mathrm{NO}^{\circ}$ modulators alone or in combination with SNP for $72 \mathrm{~h}$ when compared with the untreated group (Table 1). Since sub-G1 peaks include early and late apoptotic cells, but also a part of necrotic cells, such large sub-G1 fractions provide strong evidence for cytotoxicity induced with $1400 \mathrm{~W}$ and/or c-PTIO resulting in the decrease of the number of viable cells. Furthermore, the stage at which growth inhibition induced with 1400W and/or c-PTIO occurs in the A375 and SK mel-28 cell cycle progressions were determined, with cellular distribution in the different phases of the treatment (Table 1). Exposure of $1400 \mathrm{~W}$ and/or c-PTIO resulted in a progressive and sustained accumulation of cells in the $S$ and $G 2 / M$ phases. Further, the percentage of $S$ and $G 2 / M$ phases cells increased, while those in the G1 phase decreased after treatment with $1400 \mathrm{~W}$ and/or cPTIO $(p<0.05)$ (Table 1).

\section{A}

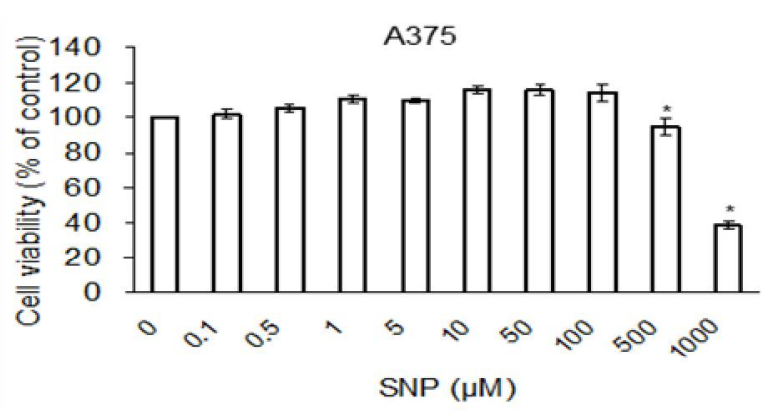

B

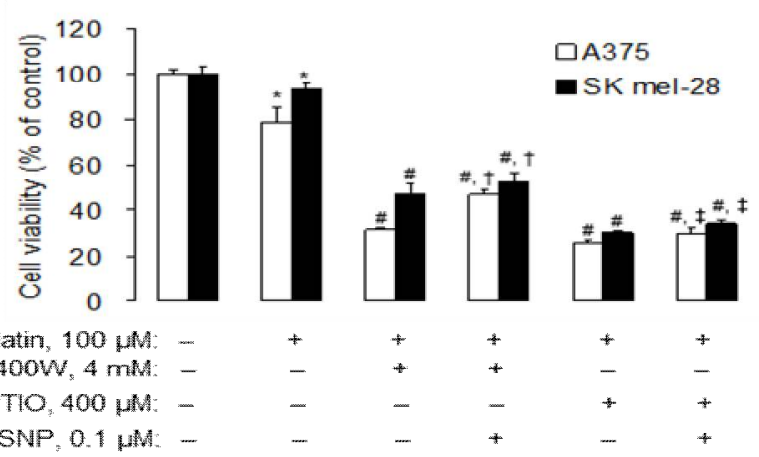

Figure 2: Regulation of $\mathrm{A} 375$ and $\mathrm{SK}$ mel-28 cell growths by endogenous $\mathrm{NO}^{\circ}$. A375 cells were treated with $\mathrm{NO}^{\circ}$ donor SNP $(0-1000 \mu \mathrm{M})$ for $48 \mathrm{~h}$, and cell viability was determined by MTT assay (A). A375 and SK mel-28 cells were treated with cisplatin $(100 \mu \mathrm{M})$ alone or combined with $1400 \mathrm{~W}(4 \mathrm{mM})$ or c-PTIO $(400 \mu \mathrm{M})$ in the presence or absence of SNP for $48 \mathrm{~h}$ (B). Results are presented as a percentage of control cells (mean $\pm \mathrm{SD}, \mathrm{n}=3$ ). ${ }^{*} p<$ 0.05 versus control; ${ }^{\#} p<0.05$ versus cisplatin; ${ }^{\dagger} p<0.05$ versus $1400 \mathrm{~W} ;{ }^{\ddagger} p<0.05$ versus c-PTIO 


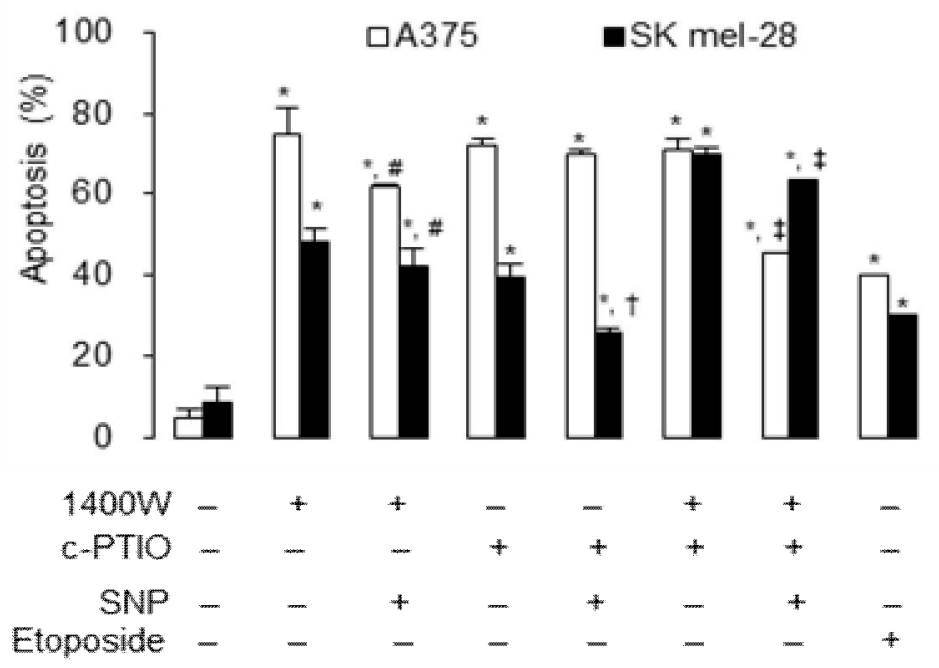

Figure 3: Apoptosis of A375 (A) and SK mel-28 (B) cells by $1400 \mathrm{~W}(4 \mathrm{mM})$ or c-PTIO $(400 \mu \mathrm{M})$ alone, or combination ( $4 \mathrm{mM}$ of $1400 \mathrm{~W}$ pre-incubated with $200 \mu \mathrm{M}$ of c-PTIO for $24 \mathrm{~h}$ ) in the presence or absence of 0.1 $\mu \mathrm{M}$ SNP treatment. Induction of apoptosis in comparison to control cultures was evaluated after double staining with FITC-Annexin V and PI. In each dot plot, the percentage of Annexin V-positive, PI-negative (early apoptosis, lower right quadrant) and of Annexin V-positive, PI-positive cells (late apoptosis, upper right quadrant) is reported. Etoposide at $50 \mu \mathrm{M}$ concentration was added to act as positive control. Values are mean $\pm \mathrm{SD}(n=3)$. ${ }^{*} p$ $<0.05$ versus control; ${ }^{\#} p<0.05$ versus $1400 \mathrm{~W} ;{ }^{\dagger} p<0.05$ versus c-PTIO; ${ }^{\ddagger} p<0.05$ versus $1400+c-\mathrm{PTIO}$

Table 1: Cell cycle distribution by $1400 \mathrm{~W}$ and/or c-PTIO in the presence or absence of SNP treated for $72 \mathrm{~h}$ in A375 and SK mel-28 cells

\begin{tabular}{|c|c|c|c|c|}
\hline \multirow{2}{*}{ Variable } & \multirow{2}{*}{$\begin{array}{l}\text { Apoptotic cells } \\
\text { (sub-G1) }\end{array}$} & \multicolumn{3}{|c|}{ Non-apoptotic cells } \\
\hline & & G0/G1 & S & G2/M \\
\hline \multicolumn{5}{|l|}{ A375 } \\
\hline Untreated control & $12.5 \pm 0.11$ & $62.6 \pm 1.10$ & $3.6 \pm 0.17$ & $21.4 \pm 0.93$ \\
\hline $4 \mathrm{mM} 1400 \mathrm{~W}$ & $43.6 \pm 1.71^{*}$ & $35.0 \pm 1.36 *$ & $5.8 \pm 0.33$ & $14.2 \pm 0.37^{*}$ \\
\hline $4 \mathrm{mM} 1400 \mathrm{~W}+0.1 \mu \mathrm{M}$ SNP & $29.3 \pm 1.08^{*}$ & $26.6 \pm 1.05^{*}$ & $14.2 \pm 0.37^{*}$ & $29.3 \pm 1.17^{*}$ \\
\hline $400 \mu \mathrm{M}$ c-PTIO & $31.8 \pm 2.14^{*}$ & $23.5 \pm 0.30^{*}$ & $12.5 \pm 0.16^{*}$ & $31.9 \pm 2.00^{*}$ \\
\hline $400 \mu \mathrm{M}$ c-PTIO + $0.1 \mu \mathrm{M}$ SNP & $32.9 \pm 0.98^{*}$ & $22.3 \pm 0.49^{*}$ & $13.1 \pm 1.15^{*}$ & $31.5 \pm 2.44^{*}$ \\
\hline \multirow{2}{*}{$\begin{array}{l}4 \mathrm{mM} 1400 \mathrm{~W}+400 \mu \mathrm{M} \text { c-PTIO } \\
4 \mathrm{mM} 1400 \mathrm{~W} \text { pre-incubated with } 200 \\
\mu \mathrm{M} \text { c-PTIO for } 24 \mathrm{~h}+0.1 \mu \mathrm{M} \text { SNP }\end{array}$} & $42.7 \pm 1.30^{*}$ & $27.7 \pm 0.23^{*}$ & $7.7 \pm 0.57^{*}$ & $21.8 \pm 1.03$ \\
\hline & $31.8 \pm 2.52^{*}$ & $28.9 \pm 0.13^{*}$ & $9.4 \pm 0.81^{*}$ & $29.7 \pm 1.34^{*}$ \\
\hline \multicolumn{5}{|l|}{ SK mel-28 } \\
\hline Untreated control & $14.0 \pm 1.79$ & $72.1 \pm 1.20$ & $5.1 \pm 0.65$ & $8.6 \pm 1.26$ \\
\hline $4 \mathrm{mM} 1400 \mathrm{~W}$ & $25.7 \pm 1.07^{*}$ & $44.8 \pm 0.09^{*}$ & $12.8 \pm 0.63^{*}$ & $15.6 \pm 1.57^{\star}$ \\
\hline $4 \mathrm{mM} 1400 \mathrm{~W}+0.1 \mu \mathrm{M}$ SNP & $26.2 \pm 1.05^{*}$ & $45.5 \pm 1.12^{*}$ & $12.4 \pm 0.74^{*}$ & $14.8 \pm 0.42^{*}$ \\
\hline 400 M c-PTIO & $34.6 \pm 1.82^{*}$ & $33.6 \pm 0.51^{*}$ & $10.7 \pm 0.23^{*}$ & $19.3 \pm 0.92^{*}$ \\
\hline $400 \mu \mathrm{M}$ c-PTIO + $0.1 \mu \mathrm{M}$ SNP & $30.5 \pm 1.53^{*}$ & $35.0 \pm 0.04^{*}$ & $11.5 \pm 0.08^{*}$ & $21.1 \pm 1.39^{*}$ \\
\hline 4 mM 1400W + $400 \mu \mathrm{M}$ c-PTIO & $30.2 \pm 0.39^{*}$ & $32.2 \pm 0.65^{*}$ & $12.7 \pm 0.11^{*}$ & $23.7 \pm 0.62^{*}$ \\
\hline $\begin{array}{l}4 \mathrm{mM} 1400 \mathrm{~W} \text { pre-incubated with } 200 \\
\mu \mathrm{M} \text { c-PTIO for } 24 \mathrm{~h}+0.1 \mu \mathrm{M} \text { SNP }\end{array}$ & $26.0 \pm 1.34^{*}$ & $32.0 \pm 0.43^{*}$ & $13.1 \pm 0.40^{*}$ & $27.2 \pm 1.34^{*}$ \\
\hline
\end{tabular}

\section{Induction of internucleosomal DNA fragmen- tation induced}

Since a major biochemical feature of apoptosis is fragmentation of the genomic DNA, we analyzed genomic DNA after treating the cells for $72 \mathrm{~h}$. Treatments with $1400 \mathrm{~W}$ and/or c-PTIO induced DNA ladder formation, confirming that apoptosis was a major contributor to cell death induced by these compounds (Figure 4).

\section{Expression of IAP family mRNA determined by semi-quantitative RT-PCR}

In this study, we subsequently investigated the mechanism underlying cell death induced by endogenous $\mathrm{NO}^{\circ}$ depletion, with a focus upon antiapoptotic activity of IAP family member. We examined expression of survivin, clAP1 and XIAP1 mRNA. Treatment of the cells with 1400W and/or c-PTIO for $72 \mathrm{~h}$ led to a reduction of survivin, clAP1 and XIAP1 in both A375 and SK mel-28 cells (Figure 5 ). 


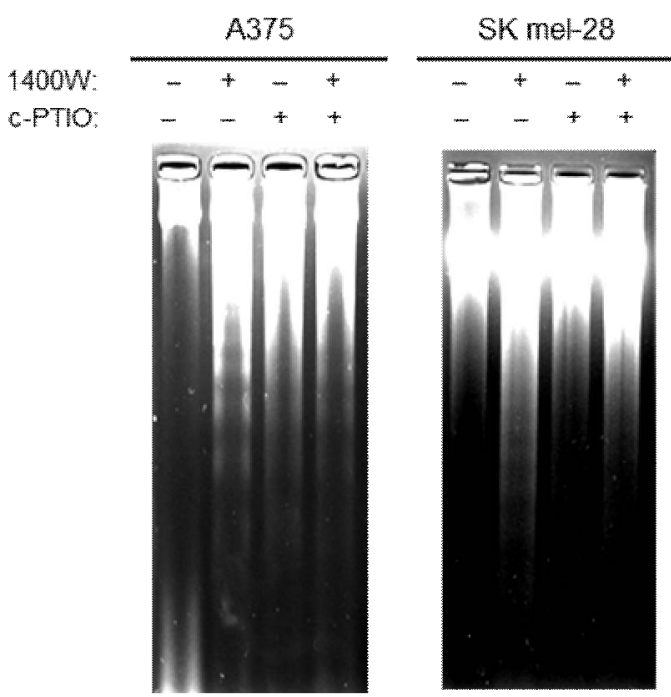

Figure 4: Apoptotic DNA fragmentation in A375 and SK mel-28 cells. Cells following incubation with $1400 \mathrm{~W}$ $(4 \mathrm{mM})$ or c-PTIO $(400 \mu \mathrm{M})$ alone, or combination (4 $\mathrm{mM}$ of $1400 \mathrm{~W}$ pre-incubated with $200 \mu \mathrm{M}$ of c-PTIO for $24 \mathrm{~h}$ ) treated for $72 \mathrm{~h}$ detected DNA fragment using agarose gel electrophoresis

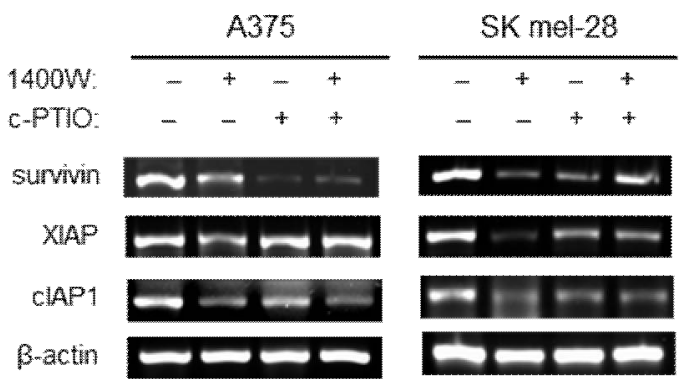

Figure 5: Expression of survivin, XIAP and cIAP1 mRNA in A375 and SK mel-28 cells after treatment with $1400 \mathrm{~W}(4 \mathrm{mM})$ or c-PTIO $(400 \mu \mathrm{M})$ alone, or combination (4 mM of $1400 \mathrm{~W}$ pre-incubated with 200 $\mu \mathrm{M}$ of c-PTIO for $24 \mathrm{~h}$ ). Semi-quantitative RT-PCR was performed using primer specific to survivin, XIAP and clAP1 or $\beta$-actin control on $1 \mu \mathrm{g}$ total RNA prepared from treated cells.

\section{DISCUSSION}

In recent years it has become evident that endogenous $\mathrm{NO}^{\circ}$ has been associated with various other tumors including melanoma and high levels of tumor iNOS have been associated with tumor progression and poor survival, although the detailed molecular mechanisms involved are not clear [17]. Understanding the mechanisms involved in the modulation of endogenous $\mathrm{NO}^{\circ}$ expression is important for the development of pharmacological strategies aimed to selectively alter the response of melanoma cells to various anticancer drugs.

Data presented here of endogenous $\mathrm{NO}^{\circ}$ was implicated in increased melanoma cell growth; cells treated with an iNOS inhibitor 1400W and $\mathrm{NO}^{\circ}$ scavenger c-PTIO decreased the percentage of viable cells, confirming that endogenous $\mathrm{NO}^{\circ}$ regulation accounts for melanoma cell proliferation. Little attention had been given to these and related questions until Ekmekcioglu et al showed recently, using in 20 human metastatic melanoma tissue specimens [10], that iNOS and nitrotyrosine expression by the melanoma cells strongly correlated with poor survival in patients with stage 3 disease, suggesting a pathway whereby iNOS might contribute to enhanced tumor progression. Use of chemical $\mathrm{NO}^{\circ}$ scavenger would nullify $\mathrm{NO}^{\circ}$ stores by quickly reacting with any newly released $\mathrm{NO}^{\circ}$, whereas inhibition of $\mathrm{NO}^{\circ}$ production by NOS does not deplete possible cellular $\mathrm{NO}^{\circ}$ storage mechanisms [5].

The cell lines used in the present study displayed p53 function attributed in sensitivity to $\mathrm{NO}^{\circ}$ modulators-induced cell death. In comparison to A375 (p53 wild-type) cells, SK mel-28 (p53 mutant) cells were resistant to $\mathrm{NO}^{\circ}$ modulatorsinduced cell death (Figures $1 \mathrm{~B}$ and $\mathrm{C}$ ). The p53 protein has broad range of biological functions, including regulation of the cell cycle, apoptosis, senescence, DNA metabolism, angiogenesis, cellular differentiation, and the immune response [18]. The key role of p53 as a tumor suppressor is to block cell cycle progression and/or to induce apoptosis, in response to cellular stresses such as DNA damage. However, mutant p53 has not only led to a loss of normal function of the wildtype protein but also led to new abilities to promote cancer [19]. Mutant p53 is frequently associated with tumor progression, resistance to therapy, and poor prognosis [20].

In the present study we report that the addition of 0.1-100 $\mu \mathrm{M}$ SNP, a NO donor, led to an increase in A375 cell growth but more than $100 \mu \mathrm{M}$ SNP caused a dose-dependent decrease in cell viability. It suggests that low levels of $\mathrm{NO}^{\circ}$ is involved in the maintenance of cell growth, whereas higher $\mathrm{NO}^{\circ}$ concentrations lead to inhibition of growth, although the threshold between low and high levels of $\mathrm{NO}^{\circ}$ is still dependent on the cell type and context within which $\mathrm{NO}^{\circ}$ is found [6]. Similar results were observed in SK mel-28 melanoma cells (data not shown). In addition, we showed the chemoadjuvant potential of $\mathrm{NO}^{\circ}$ modulators on cisplatin-mediated cell killing. Moreover, using SNP, cell growth returned to normal levels, confirming that $\mathrm{NO}^{\circ}$ plays a role as a negative regulator of cisplatin-induced cytotoxicity. These results are in close agreement with earlier reported observations that $\mathrm{NO}^{\circ}$ impairs the 
apoptotic function of cells and increases their resistance to cisplatin-induced cell death in human cancer cells [21]. Cisplatin induces downregulation of $\mathrm{Bcl}-2$ through proteasome emediated degradation. $\mathrm{NO}^{\circ}$ negatively regulates this process through its ability to nitrosylate the protein and inhibit its ubiquitination. Because increased $\mathrm{NO}^{\circ}$ production and $\mathrm{Bcl}-2$ expression have been associated with several human tumors, $\mathrm{NO}^{\circ}$ may be one of the key regulators of cell death resistance and tumor growth through S-nitrosylation [21].

The tumor suppressor p53 is activated by a variety of stress signals leading to either cellcycle arrest or apoptosis. As expected, inhibition of endogenous $\mathrm{NO}^{\circ}$ induced p53-dependent apoptosis in human melanoma cells. It therefore was suggested that tumor-associated $\mathrm{NO}^{\circ}$ production promotes cancer progression by providing a selective growth advantage of p53 mutant cells. This hypothesis of a selective growth advantage of p53 mutant cells appears plausible because high concentrations of $\mathrm{NO}^{\circ}$ and $\mathrm{NO}^{\circ}$ metabolites, such as peroxynitrite or $\mathrm{NO}_{2}^{-}$, cause DNA damage that in turn leads to p53-dependent apoptosis, but a sustained overproduction of $\mathrm{NO}^{\circ}$ also is often associated with the initiation and progression of carcinogenesis [22]. Nevertheless, p53independent processes of $\mathrm{NO}^{\circ}$-mediated apoptosis have also been reported [23], suggesting that other genes than p53 might also play an important role in the $\mathrm{NO}^{\circ}$-dependent pathways. Our data indicate that $\mathrm{NO}^{\circ}$ plays a role as a negative regulator of p53-dependent apoptosis in melanoma cells. DNA fragmentation suggested that $1400 \mathrm{~W}$ and/or c-PTIO induced cell death, involved a mechanism of apoptosis, this hypothesis was confirmed by flow cytometric analysis.

Since sub-G1 peaks include early and late apoptotic cells, but also a part of necrotic cells, such large sub-G1 fractions provide strong evidence for cytotoxicity induced with 1400W and/or C-PTIO resulting in the decrease of the number of viable cells. Furthermore, the stage at which growth inhibition induced by with $1400 \mathrm{~W}$ and/or c-PTIO occurs in the A375 and SK mel-28 cell cycle progressions were determined, with cellular distribution in the different phases of treatment. 1400W and/or c-PTIO promote cell growth inhibition by inducing $S$ and $\mathrm{G} 2 / \mathrm{M}$ phase arrests in human melanoma cells.

Activation of the NF-kB transcription factor plays an important role in the inhibitory pathway against apoptosis [24]. The IAP family such as survivin, XIAP and cIAP1 is regulated transcriptionally by NF-kB [25]. These IAPs have been reported to directly bind and repress the activation of caspases such as caspase-3 and caspase-9, indicating that expression of IAPs under the control of NF-KB plays a pivotal role in the anti-apoptotic pathway [25]. Treatment of the cells with $1400 \mathrm{~W}$ and/or c-PTIO for $72 \mathrm{~h}$ led to a reduction of survivin, clAP1 and XIAP1 in both A375 and SK mel-28 cells, suggesting the high expression of these IAPs in human melanoma cells may act as a contributing factor to resistance by these two $\mathrm{NO}^{\circ}$ modulators. However, our study provides some clues to elucidate the signaling pathways of the IAP genes because semi-quantitative RT-PCR can be highly variable and may not accurately reflect gene activity. Further study will be required to quantitatively measure IAP protein levels by western blotting.

\section{CONCLUSION}

The results of this study show that the depletion of endogenous $\mathrm{NO}^{\circ}$ inhibits the growth of human melanoma by inducing cell cycle arrest and apoptosis via IAP inhibition, which acts as a protective factor against apoptosis in human melanoma cells. p53 wild-type A375 cells were shown to be more sensitive to apoptosis induction by $\mathrm{NO}^{\circ}$ as compared to the p53 mutant SK mel-28 cells, suggesting that $\mathrm{NO}^{\circ}$ is required for p53 activation. While these findings generally support the potential utility of these compounds as cancer chemopreventive or therapeutic agents, further research will be required to define more specifically the mechanisms through which they act. Recognition that $\mathrm{NO}^{\circ}$ is a critical intermediate will facilitate progress towards that goal.

\section{DECLARATIONS}

\section{Acknowledgement}

This research was supported by 2015 Scientific Promotion Program funded by Jeju National University.

\section{Conflict of Interest}

No conflict of interest associated with this work.

\section{Contribution of Authors}

The authors declare that this work was done by the authors named in this article and all liabilities pertaining to claims relating to the content of this article will be borne by them. 


\section{REFERENCES}

1. Garbe C, Leiter U. Melanoma epidemiology and trends. Clin Dermatol, 2009; 27: 3-9

2. Chen KG, Leapman RD, Zhang G, Lai B, Valencia JC, Cardarelli CO, Vieira WD, Hearing VJ, Gottesman MM. Influence of melanosome dynamics on melanoma drug sensitivity. J Natl Cancer Inst, 2009; 101: 1259-1271

3. Szakacs G, Paterson JK, Ludwig JA, Booth-Genthe C, Gottesman MM. Targeting multidrug resistance in cancer. Nat Rev Drug Discov, 2006; 5: 219-234

4. Soengas MS, Lowe SW. Apoptosis and melanoma chemoresistance. Oncogene, 2003; 22: 3138-3151

5. Tang CH, Grimm EA. Depletion of endogenous nitric oxide enhances cisplatin-induced apoptosis in a p53dependent manner in melanoma cell lines. $J$ Biol Chem, 2004; 279: 288-298

6. Li CQ, Wogan GN. Nitric oxide as a modulator of apoptosis. Cancer Lett, 2005; 226: 1-15

7. Johansson CC, Mougiakakos D, Trocme E, All-Ericsson C, Economou MA, Larsson O, Seregard S, Kiessling R. Expression and prognostic significance of inos in uveal melanoma. Int J Cancer, 2010; 126: 2682-2689

8. Moncada S, Higgs A. The l-arginine-nitric oxide pathway. N Engl J Med, 1993; 329: 2002-2012

9. Thomsen LL, Miles DW, Happerfield L, Bobrow LG, Knowles RG, Moncada S. Nitric oxide synthase activity in human breast cancer. Br J Cancer, 1995; 72: 41-44

10. Ekmekcioglu S, Ellerhorst J, Smid CM, Prieto VG, Munsell M, Buzaid AC, Grimm EA. Inducible nitric oxide synthase and nitrotyrosine in human metastatic melanoma tumors correlate with poor survival. Clin Cancer Res, 2000; 6: 4768-4775

11. Kim MY, Trudel LJ, Wogan GN. Apoptosis induced by capsaicin and resveratrol in colon carcinoma cells requires nitric oxide production and caspase activation. Anticancer Res, 2009; 29: 3733-3740

12. Thomsen LL, Lawton FG, Knowles RG, Beesley JE, Riveros-Moreno V, Moncada S. Nitric oxide synthase activity in human gynecological cancer. Cancer Res, 1994; 54: 1352-1354

13. Xie K, Huang S, Dong Z, Juang SH, Gutman M, Xie QW, Nathan C, Fidler IJ. Transfection with the inducible nitric oxide synthase gene suppresses tumorigenicity and abrogates metastasis by $k-1735$ murine melanoma cells. J Exp Med, 1995; 181: 1333-1343

14. Juang SH, Xie K, Xu L, Shi Q, Wang Y, Yoneda J, Fidler IJ. Suppression of tumorigenicity and metastasis of human renal carcinoma cells by infection with retroviral vectors harboring the murine inducible nitric oxide synthase gene. Hum Gene Ther, 1998; 9: 845-854

15. Salvemini D, Mollace V, Pistelli A, Anggard E, Vane J. Metabolism of glyceryl trinitrate to nitric oxide by endothelial cells and smooth muscle cells and its induction by Escherichia coli lipopolysaccharide. Proc Natl Acad SciU S A, 1992; 89: 982-986

16. Abrams MJ, Murrer BA. Metal compounds in therapy and diagnosis. Science, 1993; 261: 725-730

17. Cobbs CS, Brenman JE, Aldape KD, Bredt DS, Israel $M A$. Expression of nitric oxide synthase in human central nervous system tumors. Cancer Res, 1995; 55: 727-730

18. Vousden $\mathrm{KH}$, Prives $\mathrm{C}$. Blinded by the light: The growing complexity of p53. Cell, 2009; 137: 413-431

19. Suzuki K, Matsubara $H$. Recent advances in $p 53$ research and cancer treatment. J Biomed Biotechnol, 2011; 2011: 978312

20. Bargonetti J, Manfredi JJ. Multiple roles of the tumor suppressor p53. Curr Opin Oncol, 2002; 14: 86-91

21. Godoy LC, Anderson CT, Chowdhury R, Trudel LJ, Wogan GN. Endogenously produced nitric oxide mitigates sensitivity of melanoma cells to cisplatin. Proc Natl Acad SciU S A, 2012; 109: 20373-20378

22. Ambs S, Merriam WG, Bennett WP, Felley-Bosco E, Ogunfusika MO, Oser SM, Klein S, Shields PG, Billiar $T R$, Harris CC. Frequent nitric oxide synthase-2 expression in human colon adenomas: Implication for tumor angiogenesis and colon cancer progression. Cancer Res, 1998; 58: 334-341

23. Messmer UK, Brune B. Nitric oxide-induced apoptosis: P53-dependent and p53-independent signalling pathways. Biochem J, 1996; 319 ( Pt 1): 299-305

24. Karin M, Lin A. Nf-kappab at the crossroads of life and death. Nat Immunol, 2002; 3: 221-227

25. Salvesen GS, Duckett CS. lap proteins: Blocking the road to death's door. Nat Rev Mol Cell Biol, 2002; 3: 401-410 